\title{
THE IMPACT OF AIR FREIGHT ON SURFACE TRANSPORTATION
}

\author{
ROBERT S. HENRY*
}

The commercial movement of freight by air (as distinguished from the carriage of mail, baggage, and air express) is in general a development of the postwar period. 1 American Air Lines filed with the Civil Aeronautics Board on October 15, I944, the first air freight tariff. ${ }^{2}$ It was not until r946 that the Civil Aeronautics Board (hereafter abbreviated to $\mathrm{CAB}$ ) required the volume of air freight handled to be separately shown in reports to the Board.

Competition between certificated airlines and non-scheduled all-freight carriers led for a time to widespread rate cutting, and on October 2, I947, to a CAB order for an investigation (Air Freight Rate Investigation) of the tariffs of the respective groups. ${ }^{3}$ Soon after, on October 24, I947, the CAB suspended commodity tariffs of the certificated carriers, ${ }^{4}$ and subsequently suspended any additional competitive rates below the level in effect at that date. ${ }^{5}$

As an outcome of its investigation in this case, the $\mathrm{CAB}$ made a finding that the contemporary rates for the transportation of air freight were not compensatory for either current costs or costs reasonably attainable, and it issued an $\operatorname{order}^{6}$ prescribing minimum rates of sixteen cents for the first 1,000 ton-miles (one ton moved one mile) of any one shipment and thirteen cents per ton-mile thereafter. Exceptions to these minima would be considered by the CAB, said the order, for developmental rates to promote better directional balance of traffic and to correct inequities or disparities in the rate structure. The CAB also expressed the hope that air freight operators would establish their rate structure on a level above the floor thus set. ${ }^{7}$

* B.A., IL.B. I9I1, Vanderbilt University. Postgraduate work, I919, Queens' College, Cambridge, England. Vice-President in charge of Public Relations, Association of American Railroads. Formerly lawyer and newspaper man in Nashville, Tennessee, I907-I919. Assistant to Vice-President, Nashville, Chattanooga, and St. Louis Railway, r92I-1934. Author of books on transportation and history, including This Fascinating Railroad Business (3d rev, ed. 1946); Trains (1949); Portraits of the Iron Horse (1937); ON the Railroad (I936); The Story of the Confederacy (rev. ed. 1936); The Story of Reconstruction (1938); and "First with the Most" Forrest (1944).

${ }^{1}$ Civil Aeronautics Board decision of July 29, 1949, E-3085, Air Freight Case. Dockets Nos. 810 and 730 , et al., p. 6 .

2 Torgerson, History of Air Freight Tariffs, I5 J. AIr L. AND CoM. 47 (I948).

${ }^{8}$ Motions of Air Freight Forwarder Association, et al. (Orders serial Nos. E-852, E-853).

- Order serial No. E-gr6.

${ }^{5} \mathrm{CAB}$ decision in Air Freight Investigation, E-I415, Docket No. 1705 et al., April 21, 1948, p. 4.

Order serial No. E-I415, April 21, 1948.

" CAB decision in Air Freight Rate Investigation, supra note 5, at 22. 
Volume of AIr Freight

Ton-mile figures on the movement of air freight are available for three years, as follows: ${ }^{8}$

\section{Total Freight Ton-Mítes}

i6 Certificated Carriers and 9 Non-Certificated Carriers, I946-1948

\begin{tabular}{|c|c|c|c|}
\hline Year & $\begin{array}{l}\text { Certificated } \\
\text { Carriers }\end{array}$ & $\begin{array}{l}\text { Non-Certificated } \\
\text { Carriers }\end{array}$ & Total \\
\hline$x 946$ & $\ldots \mathrm{x} 8,685,792$ & $25,183,6$ ro & $43,869,402$ \\
\hline r947 & $\ldots \ldots \ldots \ldots 3^{8,870,698}$ & $47,409,062$ & $86,279,760$ \\
\hline I94 & .......... $70,437,8 \mathrm{rr}$ & $48, \mathrm{I}$ I5,2r 8 & $1 \times 8,553,029$ \\
\hline
\end{tabular}

The relative magnitude of these movements, as compared with ton-mileages for surface transportation in these same years, is shown below: ${ }^{9}$

Total Commercial Intercity Frejght Traffic, Billions of Ton-Miles

\begin{tabular}{ccccc} 
Year & & & \multicolumn{3}{c}{$\begin{array}{c}\text { Other Surface } \\
\text { Carriers }\end{array}$} & Air \\
1946 & $\ldots \ldots \ldots \ldots \ldots \ldots \ldots \ldots$ & 602 & 272 & .04 \\
1947 & $\ldots \ldots \ldots \ldots \ldots \ldots \ldots \ldots$ & 664 & 39 & .09 \\
1948 & $\ldots \ldots \ldots \ldots \ldots \ldots \ldots \ldots$ & 648 & $35^{8}$ & .12
\end{tabular}

From the tabulations just preceding, two facts are evident. The first is that commercial air freight developed quite rapidly during the three years 1946-1948, with an increase during the period of I7o per cent. The second fact is that the impact of air freight on surface transportation of freight in general, as yet, is negligible. An air freight movement of II8 million ton-miles is an imperceptible fraction of a total intercity movement of surface freight exceeding $I, 000$ billion ton-miles. Its principal impact on surface transportation up to the present has related to the movement of railway express, which usually is considered as an adjunct to passenger transportation.

\section{II}

Future of Air Freight

However, the present situation does not necessarily reflect the future. It is appropriate, then, to examine what may be the prospects in respect to the future impact of air freight on surface transportation. Toward this end, there are two approaches. One is to examine past predictions on the subject and the extent of their fulfillment. The other is to analyze the characteristics of air freight and endeavor to evaluate its future in the light of this analysis.

\footnotetext{
${ }^{8}$ Statement of Joseph J. O'Connell, Jr., Chairman, Civil Acronautics Board, in Hearings before the Senate Committee on Interstate and Foreign Commerce, Pursuant to S. Res. 5o, 81st Cong., Ist Sess. 90, App. Io (1949).

${ }^{\circ}$ Compiled by Bureau of Railway Economics, Association of American Railroads, from official reports. of Interstatc Commerce Commission, Public Roads Administration; Chief of Engineers, United States. Army; CAB, and others.
} 
There were introduced in the Air Freight Case various estimates of domestic air freight traffic potentials at assumed rates varying from six to twenty cents per tonmile. These estimates are tabulated below: $:^{10}$

$$
\text { Source }
$$

$$
\begin{gathered}
\text { Rate } \\
\text { (Cents per ton-mile) }
\end{gathered}
$$

Edward P. Warner ..... 6

$$
\begin{aligned}
& \text { Ton-Miles, in Millions } \\
& \text { I947 }
\end{aligned}
$$

I950 2,000 5,000 300 5,600

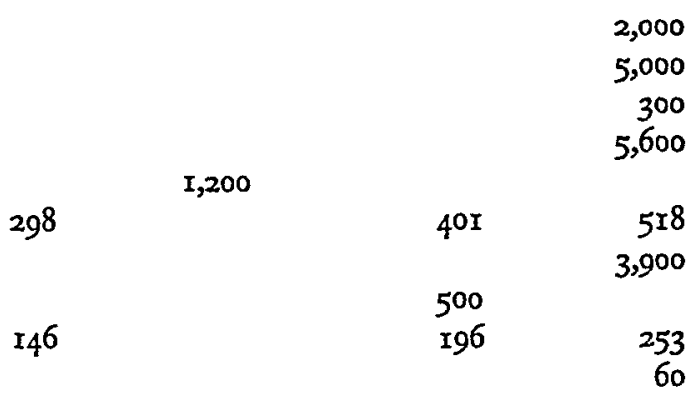

Slick Airways ......... 9

California Eastern ...... r2

Slick Airways ....... I2.5

Curtiss-Wright ........ I4

Douglas Aircraft ....... 15

American Air Express ... I5

Curtiss-Wright ........ 20

Edward P. Warner ..... 20

Commenting on these estimates, $\mathrm{CAB}$ member Harold A. Jones, dissenting, said: ${ }^{11}$ ... the examiners were, perhaps understandably, somewhat dazzled by the bright picture of the future of air cargo submitted by the applicants. They discussed [various estimates] and then concluded, more conservatively, that at the reasonably attainable rate of $I 6$ cents, a sound estimate would be one billion ton-miles per year.

Since the hearing two years have elapsed. During practically all of this period conditions for the movement of air cargo were particularly favorable and for most of the period the applicants herein were authorized to operate as scheduled common carriers. There was an unsatisfied demand for high-cost merchandise and items for which speed of transportation is particularly important-the principal sources of air freight-rail transportation was slow and somewhat overloaded, and surface freight and express rates were rising. Yet in spite of all these favorable factors, only about 86 million ton-miles of cargo was generated in 1947 and approximately 118 million in 1948 , by all domestic carriers. This was at an average rate of 12.72 cents in 1947 , and 12.68 cents in 1948 , and at a loss to all cargo carriers of very large sums of money....

A basic fact in any consideration of air freight cost is that air transport is inherently an expensive method of transportation. This situation was well stated by Robert Ramspeck, Executive Vice-President of the Air Transport Association:12

... The airplane has to physically lift everything which produces revenue while its competition has only to pull. The radical difference in basic costs of these two functions is axiomatic. Personnelwise, for example, it is estimated that it takes 2,626 employees to produce roo,000,000 ton-miles of air transportation while the railroads can produce this amount of transportation with only 72 employees.

According to an all-freight airline operator, his costs per ton-mile were 14.24 cents in 1947 and 16.39 cents in 1948 . The same operator estimated costs of the certificated airlines at from $3^{6}$ to 44 cents per ton-mile. ${ }^{13}$ A spokesman for the certificated air-

${ }^{10} \mathrm{CAB}$ decision of July 29 , 1949, Air Freight Case, supra note $\mathrm{I}$, at $\mathrm{x2}$.

${ }^{11} \mathrm{Id}$, at 21 .

12 Address before Atlanta Freight Bureau, Atlanta, Ga., Feb. I8, 1949.

${ }^{13}$ Statement of Earl Slick, President of Slick Airways, in Hearings, supra note 8, at 13. 
lines stated that the domestic trunklines had "reduced their costs per available tonmile from 32.15 cents in 1946 to 30.8 cents in 1947 , and to 30.15 cents in 1948." 14 It should be noted that the latter are costs per available ton-mile, mearring what the planes could have handled, and not the smaller traffic they did handle.

$\mathrm{CAB}$ member Jones stated in his dissent in the Air Freight Case that the rates charged for air freight are below actual costs, so that air freight has been handled "at a loss to all cargo carriers of very large sums of money," the actual average rates charged being 12.72 cents in 1947 and 12.68 cents in $1948 .^{15}$ For all domestic airmail carriers the average revenue received per ton-mile for carrying freight in the twelve months ended September 30, 1948, was 20.57 cents. $^{18}$

For ready comparison, the average revenue received by the railroads in 1948 per revenue ton-mile of freight service was 1.25 cents. All railroads do not compute their ton-mile revenue for individual commodities, but one typical railroad which does averaged 3.025 cents in 1948 for its hauls of merchandise package freight, the category which most nearly corresponds in character to air freight. Moreover, the rates which produced these levels of rail revenue had to pass the scrutiny of the Interstate Commerce Commission as being compensatory under Section I of the Interstate Commerce Act. ${ }^{17}$

The foregoing costs and rates for air freight relate only to the air movement itself. There are, in addition, the further costs paid by the shipper for getting freight to and from the airport. This is no insignificant matter. The average distance of airports from the business districts of cities served is estimated to be about eight miles. ${ }^{18}$ At relatively few large cities is the airport less than five miles from downtown. At New York, distances range from about nine miles to LaGuardia up to about seventeen miles to Idlewild International. The distance at Chicago is twelve miles. Willow Run airport is about thirty-two miles from Detroit. ${ }^{10}$ The transfer of freight over these distances, beset by city traffic and stop lights, adds a substantial element of cost.

After arrival at the airport, the next cost factor encountered is the transfer of the

\footnotetext{
1' Statement of Robert Ramspeck, Executive Vice-President, Air Transport Association, in Hearings, supra note 8 , at 418 .

${ }^{15} \mathrm{CAB}$ decision in Air Freight Case, supra note $x$, dissent, id. at 21.

${ }^{10}$ Hearings, supra note 8 , at 82 , App. 3 .

${ }^{17} 24$ STAT. 379 ( 1887 ), 49 U. S. C. \$I (1946), and amendments. "Rates which are not . . compensatory necessarily discriminate in favor of the traffic transported and unduly prejudice other traffic which must make up the loss." American Paper \& Pulp Ass'n v. Baltimore \& O. R. R., 41 I. C. C. 506, $5 I I$ (1916). "Rates may be unreasonable because too low as well as because too high." Interstate Commerce Commission v. Cincinnati, N. O. \& T. P. Ry., 167 U. S. 479 (1897), affirming 62 Fed. 690, 64 Fed. 981,76 Fed. 183,76 Fed. 1007 (C. C. Ohio $1894-1896$ ), reversing Freight Bureau, Cincinnati Chamber of Commerce v. Cincinnati, N. O. \& T. P. Ry., 6 I. C. C. I95 (1894); Excelsior from St. Paul, Minn., 36 I. C. C. 349 (1915); American Paper \& Pulp Ass'n v. Baltimore \& O. R. R., 4I I. C. C. 506 (igi6). I Interstate Commerce Acts Annotated 389 (Aitchison ed. 1930).

${ }^{18}$ Association of American Railroads (AAR), Railroad Committee for the Study of Transportation (RCST), Subcommittee on Air Transport (SCAT), Air Transportation 49 (I947).

${ }^{19}$ Out at the Airport (American Road Builders' Ass'n, March, 1949). AAR, RCST, SCAT, Initial Study of Atr Transportation 34 (1944).
} 
freight to the plane and its stowage for flight. This calls for the use of various types of loading methods and devices. ${ }^{20}$

Loading a plane, too, involves problems not met in surface transportation. The weight of plane cargo has to be accurately computed, and the distribution of the load in the plane is also highly important to safety of operation. It has been suggested that, in respect to weighing freight for loading, time could be saved by loading planes on balance scales located in the apron, but the degree of error introduced by wing and air conditions probably would be too great for acceptance of this method. ${ }^{21}$ Moreover, this is a continuing problem; each time that some cargo is off-loaded or new shipments taken aboard brings a new problem of weight and balance requiring to be immediately, expertly, and accurately solved.

At the same time, the necessity for proper load distribution requires stowage of cargo according to weight and density characteristics, rather than according to destination, which often entails considerable extra handling when loading and unloading freight. ${ }^{22}$ Finally, stability of the load during take-off, flight, and landing requires that cargo be securely anchored; a shift of position could seriously endanger the plane and its occupants. This situation involves the use of various kinds of bins, load stabilizers, and tie-downs. These must be suitable for quick attachment and removal, involving the use of fixtures which the plane design may not always facilitate. In any event, their use involves extra expense, ground time, and cargo handling.

Adding up all these items of expense, the conclusion is inescapable that air freight is inherently bound to be much more costly than surface transportation. It is true that air transport has some characteristics which might at times offset some of these costs. For example, air freight rates are based on airline distances, which usually are less than surface transport distances. To the extent of such differences, the tonmile cost of air freight is subject to some discount in comparison with surface ton-mile costs.

In some instances, too, packing required for surface transport can be lessened or discarded for air transport. However, beneath this apparently simple statement lie troublesome complications. For example, garments can be shipped by air on racks without packaging-but to get such garments to and from the airport requires trucks as well as planes to be equipped with special racks. ${ }^{23}$ Packaging needs incident to handling to and from the airport, on and off the plane, and stowage enroute, have to be considered as well as the actual plane trip. There is also the fact that air freight schedules directly serve only about 400 localities in the country, so that packaging must take into account the need for movement by some other form of transportation to all other destinations. Again, in order for a shipper to avail him-

${ }^{20}$ Scragg, Mechanical Handling of Air Freight, $8 x$ TrAfFic Word. 489 (1948).

${ }_{21}$ Pack, Air-Cargo Handling, Mechanical Engineering, July, I945, p. 467.

${ }^{22}$ Col. Harold R. Harris, Chief of Staff, Air Transport Command, address before American Society of Mechanical Engineers, New York City, March 12, 1945.

${ }^{23}$ Penzell, Trucks, Flying and Otherwise, Distribution Age, October, 1946, pp. 37, 75. 
self of such advantages of lessened packaging as the plane may offer, he must either ship all his goods by plane, stock goods packaged differently for surface and for plane transportation, or else make special packages for his air shipments. The complications and costs here involved are obvious.

\section{III}

\section{Types of Potential Freight}

On the premise that air freight is bound to be much more costly than surface transportation, what kind of freight can pay these greatly increased transportation costs? What does the buyer of air freight seek that makes him willing to pay such a substantial premium over surface transporation?

By and large, the answer is speed, which is another way of saying "time." Potential air freight logically would be, therefore, commodities in the handling and merchandising of which time is of high importance. Experience shows that this is indeed the case.

A prewar analysis of air express movement-the direct ancestor of air freightshowed that the principal goods then moved by air were newspapers, books, printed matter, and printing materials; parts and supplies; documents and valuables; wearing apparel; motion picture film; phonograph records; and miscellaneous articles. Analysis of postwar air freight traffic shows that the character of the goods has not changed a great deal. Of the major classes of commodities transported by two allfreight air carriers in 1945 and 1946 , the principal items were cut flowers; fabrics and apparel; magazines, other printed matter, and printing material; and miscellaneous; with fresh fruits and vegetables amounting to about one-eighth of the total for each of the two carriers. ${ }^{24}$

The failure of air freight to develop new traffic has been conspicuous. Commenting on this fact, $\mathrm{CAB}$ member Jones said:25

At the conclusion of the hearing in January, 1947, the record showed that approximately two-thirds of "air cargo" consisted of wearing apparel, cut flowers and industrial parts.... Claims were made of a tremendous potential in a great variety of commodities not previously moving by air.... The record of experience over the two years since the hearing does not bear out such predictions. Approximately the same relative amounts of the same three commodities are now being carried by the applicants-wearing apparel, cut flowers, and parts-which have been the backbone of property carriage by air since its inception.

Commenting on the air movement of fresh fruit and vegetables, about which there has been much optimism, CAB Member Jones said: ${ }^{26}$

Various forecasts submitted to the examiners estimated a tremendous future movement of fresh fruits and vegetables. ... What has experience shown? The two all-cargo carriers operating transcontinentally ... carried between them between the West Coast and

${ }^{24}$ Drew and Passen, Air Cargo: A New Force in Marketing, I4 J. AIr L. AND Com. II, I7 (1947).

${ }^{25} \mathrm{CAB}$ decision of July 29, 1949, E-3085, Air Freight Case, Dockets Nos. 810 and 730, dissent, p. 22.

${ }^{20} I d$. at 23. 
New York, probably the most promising route for the development of agricultural traffic, during four representative months [in I947-1948] a grand total of II shipments of such products, weighing less than a thousand pounds in the aggregate. The certificated carriers show similar results.

As the cost of air freight may decline, an increase in its traffic volume may be expected. For example, one exhaustive study of air freight possibilities says on this point::27

... at a rate of $x_{5}$ cents per ton-mile for the line haul alone, an insignificant amount of produce traffic is likely to be diverted to air. At a rate of ro cents the volume of traffic in sight is still only negligible. However, at 7 cents per ton-mile . . . definite commercial possibilities begin to appear.

The future prospects of air freight, therefore, depend in large degree upon the margin by which air freight costs may exceed surface costs for freight transportation.

On this point there appears to be at this time no great amount of informed optimism. The most recent and informed official judgment of the extent of the air freight potential was expressed by the $\mathrm{CAB}$ in its decision in the Air Freight Case. It said there: ${ }^{28}$

It is recognized that air freight, in its present stage at least, is a relatively high cost medium of transportation and the cost, aside from other factors, would act as a deterrent to any appreciable movement of the greater percentage of products now moving in interstate commerce. ...

On the basis of the facts of record relating to traffic and air freight potential, we conclude that even in the absence of unusual technical advances which would permit substantially lower rates, there is a potential domestic traffic for air freight of not less than one billion ton-miles annually.

This estimate of one billion ton-miles for air freight compares with a total intercity freight movement in 1948 of 648 billion ton-miles by rail and 1,006 billion tonmiles by all forms of intercity surface transportation. ${ }^{29}$

However, this $\mathrm{CAB}$ estimate of one billion ton-miles potential has been termed by well-informed sources over-optimistic. For example, CAB Member Jones said: ${ }^{30}$

There are no "facts of record" which I can find to support such an estimate. . . .

... It should be noted that the majority rather obviously fails to relate the one billion ton-mile figure to any particular period. For all the opinion indicates, the estimate might be for $5^{\circ}$ or 100 years from now. . .

... This [I947 and I948] tonnage was carried at a rate level which, as the record shows, was uneconomical and which must be substantially increased. Nor do the facts in the record tend to prove any reasonable prospect of advancement in the art in the near future which will reduce costs, thereby making lower rates possible.

\footnotetext{
${ }^{27}$ Spencer A. Larsen, Air Cargo Potential in Frese Fruts and Vegetables 2 (ig44).

${ }^{28} \mathrm{CAB}$ decision of July 29, I949, supra note 25 , at II, 22.

${ }^{20}$ See note 9 supra.

${ }^{30} \mathrm{CAB}$ decision of July 29, I949, Air Freight Case, supra note 25, at 29-33.
} 
The costs which have so far been experienced are little more than the bare costs of operating aircraft. Even these will inevitably increase with the passage of time after certification ... depreciation expense is considerably below what will be incurred in the future.

All in all, there is nothing whatever in the record to support a conclusion that the applicants' costs will decrease with certification, but rather to the contrary. And in the face of a loss experience of 3 cents per ton-mile, it is completely unrealistic to assume that the level of freight rates will not of necessity increase substantially in the near future.

In exceptions to the tentative decision in the Air Freight Case, United Air Lines said projections based on past increases would indicate about 250 million ton-miles in I953, compared with the Board's estimated potential of one billion ton-miles, or four times as much. ${ }^{31}$

Dr. John H. Frederick, aircargo consultant and for many years an outstanding student of air transport economics, says of the $\mathrm{CAB}$ estimate, "Its vision of one billion ton-miles is Jules Verne, if anything." ${ }^{22}$

IV

\section{Full Air Freight Costs UnKNown}

In his analysis, just cited, $\mathrm{CAB}$ member Jones called attention to the fact that air freight thus far has been operated at a loss, and that its unit costs are more likely to increase than to decline. The fact is that no one knows what are the real costs of air transportation. They are higher than the revenues received for the service, but how high they actually are still remains to be ascertained.

Any such cost computation needs to take into account all costs of air transportation, including those items borne by the general taxpayers as well as such costs as are borne directly by the users of the service. Not until the rates of competing carriers fully reflect all costs of the service can an informed decision be made as to which service is the most economical and efficient for a given transportation task. And only in the light of such informed decisions can competition among various forms of transport be on a basis which is fair to the carriers and compatible with the public interest in sound transportation conditions.

Beyond question, carriers handling traffic at rates which do not meet operating costs offer uneconomic and unjust competition with other carriers. It is abundantly evident in the record of the Air Freight Case ${ }^{33}$ and of other proceedings ${ }^{34}$ that present rates for air freight do not meet operating costs. To be specific, Public Counsel in that case pointed out that all the freight carried by the three major noncertificated applicants who had supplied data had been carried at an average loss of 4.23 cents for each ton-mile carried. ${ }^{35}$

sx United Air Lines Brief, May 18, 1949, p: I2.

32 Frederick, Areas for Aircargo, Distribution Age, July, 1949, pp. 37, 53.

${ }^{33} \mathrm{CAB}$ decision of July; 29, x949, Air Freight Case, supra note 25, at 20, 21; Jones dissent, id. at 2I, 40 (inter alia).

34 Statement of Senator Edwin C. Johnson, Chairman, Interstate and Forcign Commerce Committec, in Hearings, supra note 8; statement of Joseph J. O'Connell, Chairman, Civil Aeronautics Board, ibid.

${ }^{35} \mathrm{CAB}$ decision of July 29, 1949, Air Freight Case, Lee dissent, stupra note 25, at 2. 
In respect to the domestic certificated airlines, it is impossible to be thus specific, because their expenses apply to their joint passenger, mail, and freight operations, of which no segregation for cost accounting purposes is available. However, it is a matter of record that, despite repeated increases in mail pay under Section 406(b) of the Civil Aeronautics Act of 1938, the operating expenses of these lines have exceeded or closely approached the operating revenues after mail pay subsidy, and that postwar losses of the domestic trunk airlines before mail pay had increased as their volume of traffic increased. Illustrative are the following figures for these airlines: ${ }^{38}$

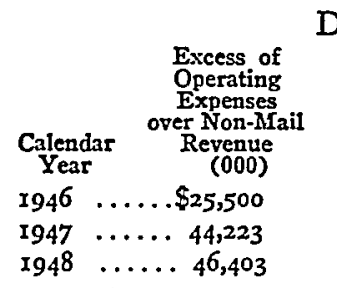

* Subject to final adjustmen Domestic Air Carriers-All "Trunk Lines"

That the rates charged by these airlines for their passenger and freight service as a whole are below operating costs is the obvious inference from these figures.

There can be no doubt that the mail subsidy payments to the certificated airlines afford them a competitive advantage. These payments can be used to defray part of their full cost of operating freight or passenger service, and thus enable such service to be sold at less than would otherwise have to be charged for it, and less than it actually costs.

\section{$\mathrm{V}$}

\section{Subsidies Other Than MaIL Pay}

What is true of the mail pay subsidy to the certificated airlines, as just stated, is true in corresponding degree of the several other government subsidies from which all air transport operators benefit. These include: (I) construction and maintenance of airports; (2) traffic regulation and control; (3) special weather service for aviation purposes; (4) safety regulations and practices; (5) airman and aircraft licensing and inspection; and (6) maintenance of government promotional authorities.

The sums of money involved in these activities are of such magnitude that they have appreciable effects upon the national budget, upon state and municipal budgets, upon the air transport industry itself, and upon other carriers affected by the activities of air transport.

\section{A. Airport Costs}

In regard to construction and maintenance of airports, D. W. Rentzel, Administrator of Civil Aeronautics, testified before the Senate Interstate and Foreign Commerce Committee on April 14, 1949, as follows:37

\footnotetext{
${ }^{80}$ See Hearings, supra note 8, App. $2 \mathrm{D}$ and $2 \mathrm{~J}$, at 75, 79.

${ }^{37}$ See Hearings, supra note 8 , at $\mathbf{I 7 7}$.
} 
... Taxpayers of the United States have an investment of about one and one-half billion dollars in civil airports. Of the larger airports, which were financed by Federal, State, and local appropriations, only a handful are self-supporting even to the extent of returning out-of-pocket operating and maintenance expenses.

Another authoritative statement on this subject appears in a report issued by the House Committee on Interstate and Foreign Commerce as a part of its National Transportation Inquiry, under the title "Public Aid to Air Transportation."38 This report states that the "estimated net cost to the taxpayers" for operation and maintenance of airports (as of the end of r945) is $\$ 56,187,500$ per year. The percentage of use by scheduled air carriers was shown in that report as 20.03 per cent in r946, and 16.15 per cent in 1947 . At the twenty-five leading airports, the proportional use by scheduled air carriers was stated as 33.6 per cent in 1946 and 34.4 per cent in 1947 . These allocations are on a basis which takes no account of the size and weight of planes nor of the effect thereof on the length, strength, and cost of the runways needed.

\section{B. Federal Aids to Air Navigation}

Appearing before the Senate Committee on Interstate and Foreign Commerce on April 25, 1949, J. Weldon Jones, Assistant Director in Charge of Fiscal Analysis, Bureau of the Budget, testified that expenditures by the Federal Government on the principal programs for promotion and assistance of civil aviation through mail subsidy to the airlines and through the free provision of air navigation facilities and other services in FY-r949 would amount to about $\$ 300$ million. Of this amount, he said, $4^{\circ}$ per cent is for mail pay and is subject to adjustment as the result of further rate revisions still pending. Any such adjustment in mail pay, of course, would be upward. He added that he expected the corresponding figure for FY-r950 to be about $\$ 35^{\circ}$ million, without allowing for any increase in mail pay..$^{30}$

The House Report referred to above stated (p. II) that the total cost of maintaining and operating federal aids to navigation (beacons, radio, weather service, control towers, etc.) is computed by the Civil Aeronautics Administration at $\$ 39,57$ 1,087 per year, "no part of [which] is borne by commercial air transport nor have the air lines ... invested any money in these facilities." This cost is undoubtedly greater today. Scheduled air carriers utilize these navigation aids in varying proportions up to. 80 per cent of the total.

Federal appropriations to the Civil Aeronautics Administration also inure to the benefit of air carriers. The duties of the CAA are not concerned with regulation in the ordinary sense of the word (which devolves upon the $\mathrm{CAB}$ ), but with promotional and supervisory activities, which are of undoubted benefit to air carriers, but which in the case of surface carriers are performed for the most part at their own expense. Considerable stress was laid upon these promotional functions by the $\mathrm{CAB}$ in its decision in the Air Freight Case. ${ }^{40}$

\footnotetext{
${ }^{38}$ H. R. 1612, 8oth Cong., 2d Sess, 9, ro (1948).

${ }^{30}$ See Hearings, supra note 8 , at $324-325,326-327$.

${ }^{10} \mathrm{CAB}$ decision of July 29, 1949, Air Freight Case, supra note 25, at $27 \mathrm{ff}$.
} 
All of these, and other, kinds of public aid to air navigation are supplied by the government without cost to the users. How much of such cost should properly be regarded as constituting a subsidy to air transport is not now known.

There is hope that the air transport industry at some future date will become selfsupporting. To realize the fulfillment of that hope, there must be thorough ascertainment and knowledge of the amounts involved in these subsidies, even if they are stated only as a goal on the way to attainment of self-support. As President W. A. Patterson of United Air Lines said in his testimony before the Senate Interstate and Foreign Commerce Committee $:^{41}$

With subsidy being identified directly as such, it would serve as an incentive for management to increase its efforts to reduce and eliminate subsidy.

He was then speaking of the subsidy element in mail pay, but his statement would appear to be equally applicable to subsidy in any form.

Until all subsidy is eliminated, the rates of subsidized carriers will not fully reflect all the costs of the service. Until rates do fully reflect all the costs of providing the service, the respective merits of the various types of carriers from the standpoint of efficiency and economy will be obscured, and competition among carriers will remain on a fallacious basis. While such a basis prevails, evaluation of the impact of air transport upon surface transport cannot be accurately made, because the outcome will depend upon government subsidy policies as they may be effective from time to time.

VI

\section{Conclusions}

r. Air freight has been in existence only about three years and has attained a maximum volume of $x 18$ million ton-miles, in $x 948$. This compares with 648,000 million ton-miles by rail and $1,006,000$ million ton-miles by all forms of intercity commercial surface transportation in that year.

2. Air transportation is inherently a costly form of movement, because power must be expended to sustain as well as to move the load. In addition, movement to and from airports-usually at a considerable distance from business districts, through urban traffic-and loading and stowage on the plane are added cost factors. Such factors of higher cost may be partly offset in occasional instances by more direct airline distances and lessened packing requirements for air movement.

3. Air freight competition with surface carriers thus far has been conducted at prices below operating costs-a situation which cannot continue.

4. The costs of air freight movement to date include only those costs directly borne by the carriers-they do not include costs borne by the general public in the form of subsidies of various kinds.

\footnotetext{
"See Hearings, supra note 8.
} 
5. Until all the costs of air transport are paid by air carriers-or at least are fully known and recognized for what they are-there can be no conclusive determination of the place of air freight in the transportation picture, on the basis of its relative economy and efficiency.

6. However, failing some invention or discovery, not now foreseen, which will greatly reduce costs of air movement, it seems improbable that on an economic basis air freight can seriously affect the volume of traffic or the rates of surface carriers. 